\title{
PERSPECTIVES OF THE AIR TRANSPORTATION MARKET IN UKRAINE
}

\author{
Tamara OLESHKO, Iryna HEIETS* \\ National Aviation University, 1 Kosmonavta Komarova Ave., 03680 Kyiv, Ukraine
}

Received 20 December 2017; accepted 29 January 2018

\begin{abstract}
The paper considers the current situation in the air transportation market in Ukraine. It is shown that, in the Ukrainian segment of the global aviation market, the effectiveness of passenger traffic and air transportation in reference to passenger per kilometer may grow in national and international flight routes. The authors justify the rapid increase in civil aviation efficiency and high capability of the air transport industry of Ukraine, taking into account the global rates of civil aviation development.
\end{abstract}

Keywords: civil aviation, airlines, air transportation market, air traffic, passenger traffic, load factor, air transport.

\section{Introduction}

The air transport industry has experienced a rapid development followed by an average annual growth rate equal to almost 10 per cent over the past 55 years. This rate exceeds the average growth of the gross domestic product (GDP) three times. A certain increase in the volume of air transportation has been achieved as a result of technological advances, high level of productivity demonstrated by manufacturers, enhanced goods consumption, and liberalization pertaining to air transport markets.

Civil aviation can benefit from and contribute to the economic development of states provided that effective interaction in various sectors of economy is ensured. To emphasize the role of air transport in the economic development of states and regions, it is necessary to take into account the economic and social benefits that an efficient air transport system can offer.

\section{Case analysis}

The level of global economic development is increasing significantly thanks to air transport efficiency. This economic benefit is a result of improving connections between cities, which, in turn, enables the flow of goods, people, finances, technologies, and ideas. With this in mind, it is safe to say that expenses on air transport are to be decreased. In air transportation, the number of connections between cities of origin and cities of destination is expected to reach more than 19,000 in 2017. In comparison with the situation twenty years ago, the volume of air transportation has demonstrated an almost double increase (see Figure 1). Having been adjusted for inflation, the costs of air transport for users continue to fall.

Governments have had substancial gains from the efficient performance of the air transport industry (Harrison, 2005; Alamdari, 2010). Airlines are forecast to generate $\$ 124$ billion in tax revenues in 2018 (see Figure 2).

Air transport is vitally important for the trading of goods produced by various manufacturers, in particular for the trading of separate parts for a certain product, for instance aircraft parts (Miziuk, 2014). This kind of trading is a major element of cross border trade today. According to the forecast performed by the WTO (World Trade

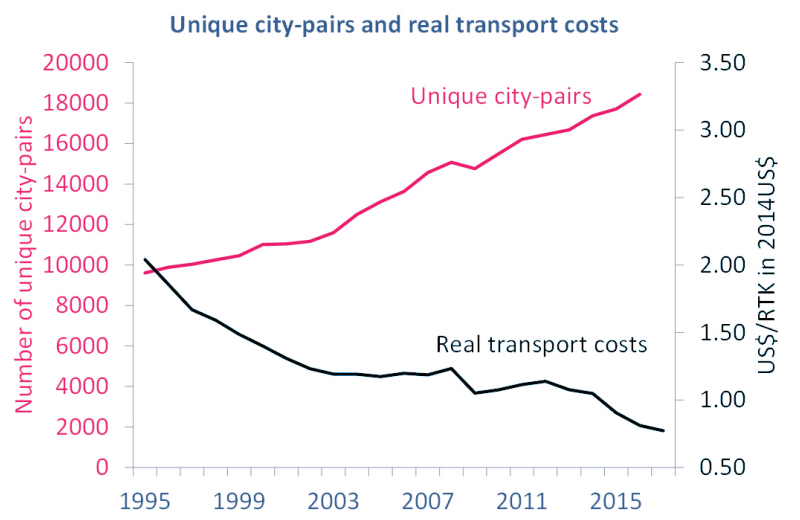

Figure 1. Analysis of costs of air transport and the number of connections between cities of origin and cities of destination

*Corresponding author. E-mail: heietsiryna@gmail.com 


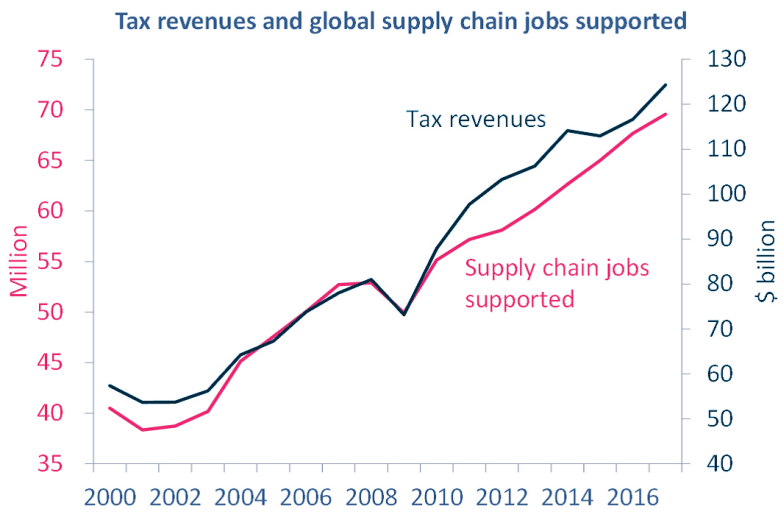

Figure 2. Global tax revenues gained from activities of airlines

Organization, 2016), the benefits that can be gained from international trade carried out by means of air transportation will reach $\$ 5.9$ trillion in 2018 . With this in mind, it should be noted that $\$ 685$ billion are predicted to be spent in the area of air tourism in 2018.

A positive influence of air transport on the global economy has been enhanced in reference to the effective employment in the area of civil aviation and other industries having economic relations with it (Belobaba, Odoni, \& Barnhart, 2015). This leads one to conclude that national economies can obtain financial resources equal to 69.6 million owing to the creating of new jobs in 2018 (IATA, 2016).

In many countries, the value of aviation to the economy has not received much attention lately. Yet, effective commercial activities performed by airlines enhance the interest of passengers in air tourism (Kulayev \& Shchelkunov, 2010).

In 2018, commercial airlines are expected to receive around 1,850 new aircraft, which is deemed to be a substantial investment into the aviation industry (Figure 3). The sufficient average cost recovery tends to give airlines an opportunity to obtain investments (IATA, 2016). The trends in the global market foster the process of substitution carried out by airlines in reference to aircraft fleets with high fuel consumption. In the future, airlines ought to be able to operate aircraft with higher efficiency. This objective can be achieved due to the decrease in fuel costs (Ozer \& Phillips, 2012).

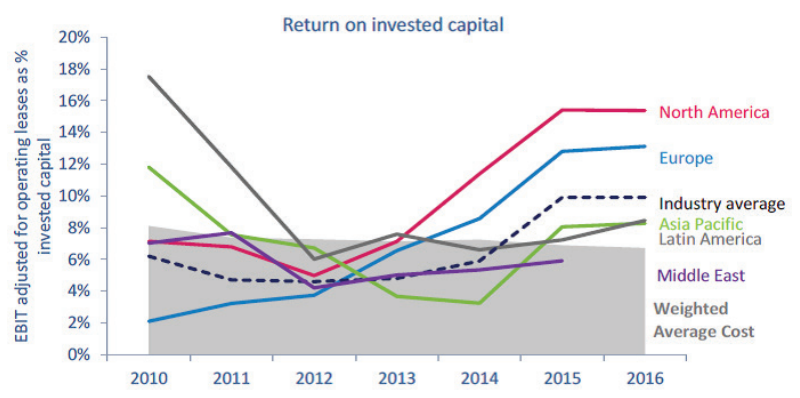

Figure 3. Return of financial resources invested into civil aviation development
In 2016, the Ukrainian air transportation market managed to overpower the crisis and demonstrated higher results in comparison with 2013 . The values obtained in 2013 are standard ones to compare the achievements of the modern economy of Ukraine (Oleshko \& Heiets, 2017).

According to State Aviation Administration of Ukraine (2016a), in the year 2016, the number of passengers carried by air transport in Ukraine reached 8.27 million, which is $31.3 \%$ higher than in the same period in 2015. Moreover, this number exceeded the value obtained in 2013 (8.11 million passengers) by $2.1 \%$ (Figure 4 ).

In the Ukrainian air transportation market, the national airlines carried 4.944.400 passengers, whereas foreign airlines carried 3.487.500 passengers (an increase equal to $23 \%$ for national airlines and $2.1 \%$ for foreign airlines in comparison with 2015). Taking into consideration that Ukraine has temporarily lost two large airports such as the Simferopol International Airport and the Donetsk International Airport, it is safe to say that the air transportation market has overpowered the crisis.

The leading positions in the aviation market of Ukraine have been taken by the following airlines: "Ukrainian International Airlines", "Azur Air", "Wind Rose", "YanAir", "Bravo", and "Atlasjet Ukraine". These airlines conduct 95\% of all passenger carryings performed in Ukraine.

The growth in passenger traffic by a third in comparison with 2015 is connected with a $24.9 \%$ increase in air transportation volumes achieved by Ukrainian International Airlines. This increase was achieved due to both the establishment of a large number of new flights, including long-haul flights and 9 new planes introduced into the aircraft fleet.

In 2016, the number of passengers carried by YanAir Airlines exceeded the values obtained in 20156.8 times. Wind Rose Airlines increased their values by $75.8 \%$ in 2015, and Azur Air Airlines, in turn, increased its passenger traffic by $17 \%$. These data have been confirmed by financial statistics. It is necessary to emphasize that, in a financial equivalent, the national airlines provided services for as much as 21.6 billion hryvnias (UAH) in 2016, which is 10 billion UAH more than in 2015.

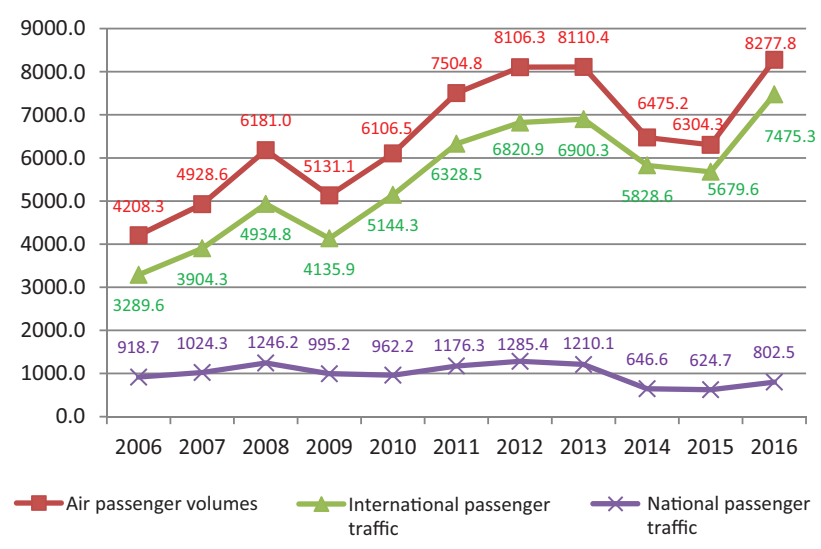

Figure 4. Volumes of passenger transportation by air in 2006-2016 
Twenty nine Ukrainian airlines (19 of which are engaged in passenger transportation) performed 79.5 thousand commercial flights in 2016, compared to 66.3 thousand flights in 2015. There were 40 national airlines that performed 96 thousand flights in 2013, which is shown in Figure 5. In 2016, Ukrainian airlines began operating 27 international routes on a regular basis; foreign airlines began operating 13 routes according to a schedule.

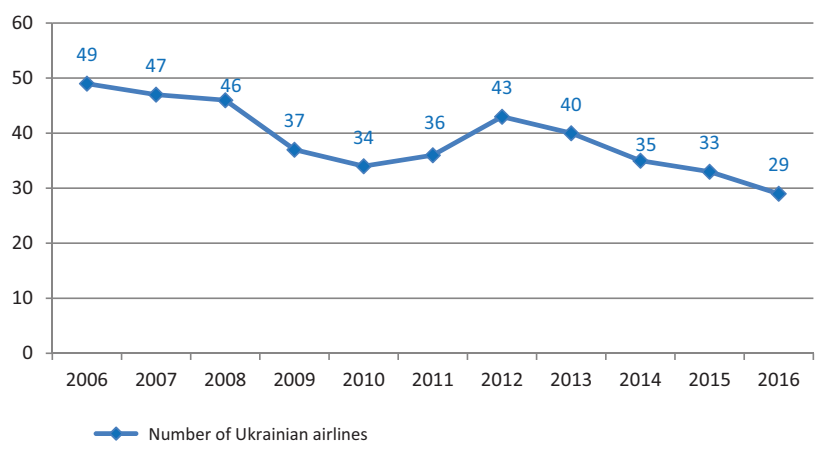

Figure 5. Number of Ukrainian airlines that carried out commercial transportation of passengers, cargo and mail in 2006-2016

Ten Ukrainian airlines are currently performing scheduled flights to 42 countries, and 28 foreign airlines, in turn, are flying to 27 countries (Figure 6). Nevertheless, according to the analysis of the period from 2006 to 2016, the number of foreign airlines has decreased by two. In 2016, two new foreign airlines entered the Ukrainian market - "Sprint Air", an airline from Poland (performing flights from the airport of Radom to Lviv), and "Air Serbia", an airline from Serbia (flights from Kyiv to Belgrade) (State Aviation Administration of Ukraine, 2016b).

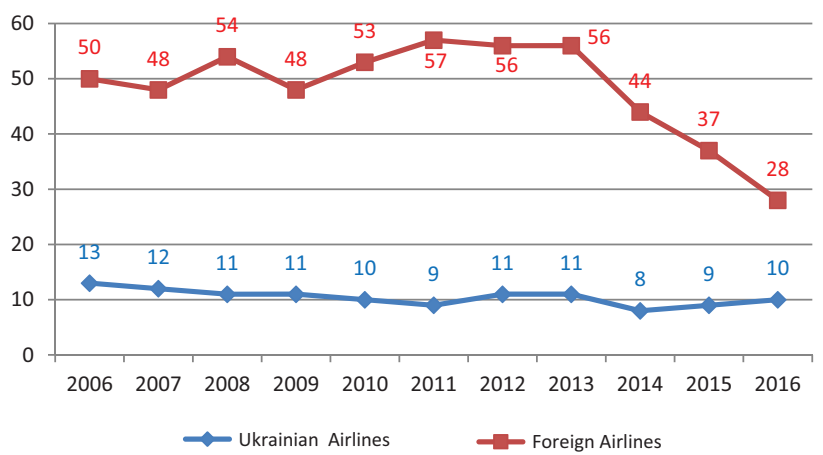

Figure 6. Number of Ukrainian and foreign airlines which carried out regular international passenger transportation from/to airports of Ukraine in 2006-2016

The establishment of new flight routes to various countries was a result of the prohibition on air connection with Russia, which came into force on October 25, 2015. However, Ukrainian national airlines did not take a full advantage of this situation. The biggest winners were the following foreign airlines: "Belavia" from Belarus and "Turkish Airlines" from Turkey, which benefited to a greater extent.

At present, the Belarusian carrier flies to Ukrainian airports such as "Boryspil", "Kyiv", "Kharkiv", "Odesa", "Lviv" in accordance with a signed agreement on joint airway operation with the airline "Motor Sich" from "Zaporizhia". The temporary situation in the Ukrainian air transportation market al.owed "Belavia" to increase passenger traffic in Ukraine by more than a double.

Considering that Ukrainian national airlines increased passenger transportation on international flights by $23 \%$, which is equal to 4.94 million people, the foreign airlines achieved an increase equal to $2.1 \%$ only (3.84 million people).

The national air transportation market is developing at an acceptable tempo. Passenger traffic between Ukrainian cities increased by $29.5 \%$ in 2016 , which was equal to 791.9 thousand people.

Nowadays, four national airlines carry out regular passenger transportation within Ukraine, namely "UIA", "Dniproavia", "Bravo", and "Motor Sich" perform flights between 9 cities of Ukraine. Figures 7 and 8 show passenger kilometers and passenger traffic (national and international) for the period from 2006 to 2016.

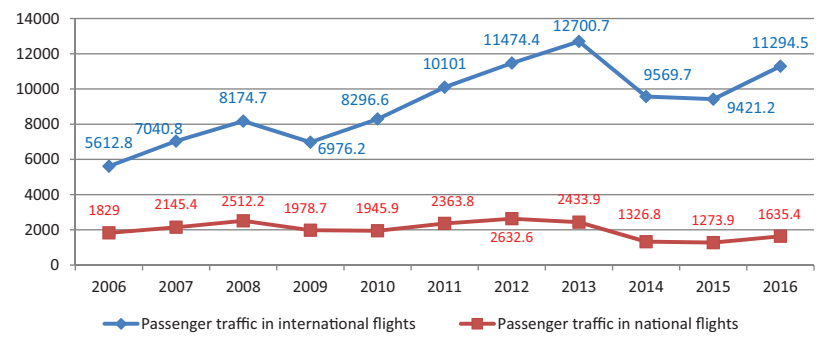

Figure 7. Passenger traffic in international and national flights, 2006-2016

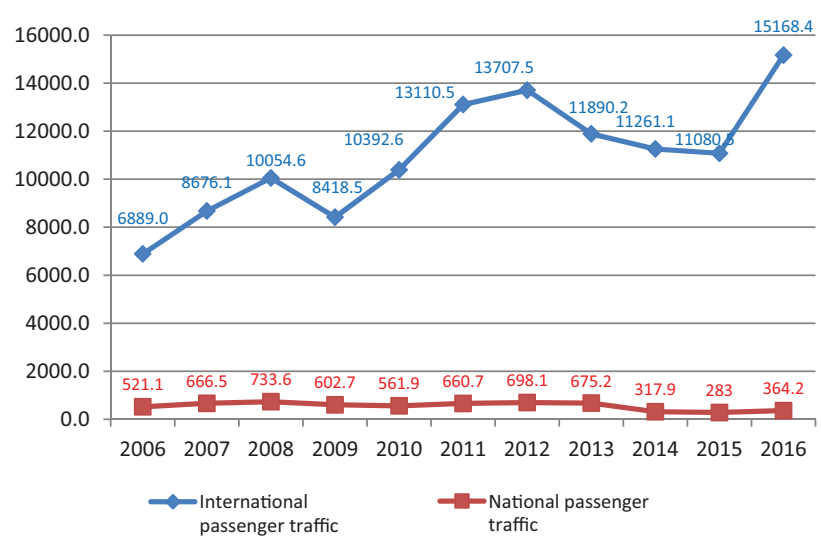

Figure 8. Air transportation efficiency in reference to passenger per kilometer, 2006-2016

International charter air transportation increased by $52.5 \%$ in 2016. Fifteen Ukrainian airlines carried 2.53 million passengers while operating non-scheduled flights. $91 \%$ of passengers were transported by such airlines as "UIA", "Azur Air", "Wind Rose", "YanAir", and "Bravo". In 2016, the load factor in international flights conducted by Ukrainian airlines equaled $78.2 \%$; for national flights this factor reached $73.3 \%$ (Figure 9). 


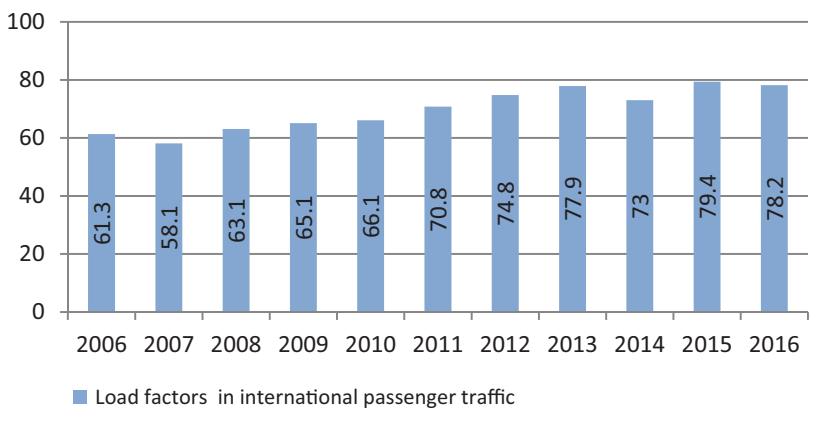

Figure 9. Load factor in international passenger traffic of Ukrainian airlines, 2006-2016

Evaluating the load factor values from a global perspective, it is clear that the average load factor in international passenger traffic in Ukraine exceeds analogical values in other regions of the world (Figure 10). As illustrated in Figure 11, at the end of 2016, the number of departing and arriving aircraft equaled 133.200 (compared to 120.700 in 2015) (State Aviation Administration of Ukraine, 2016b).

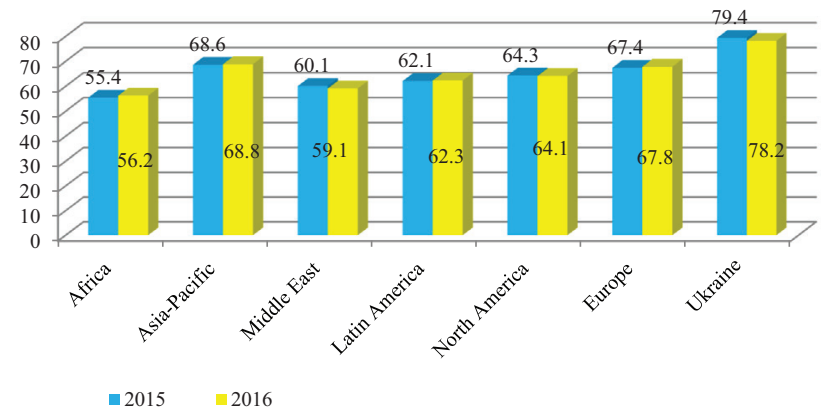

Figure 10. Load factor in international passenger traffic in Ukraine and other regions of the world

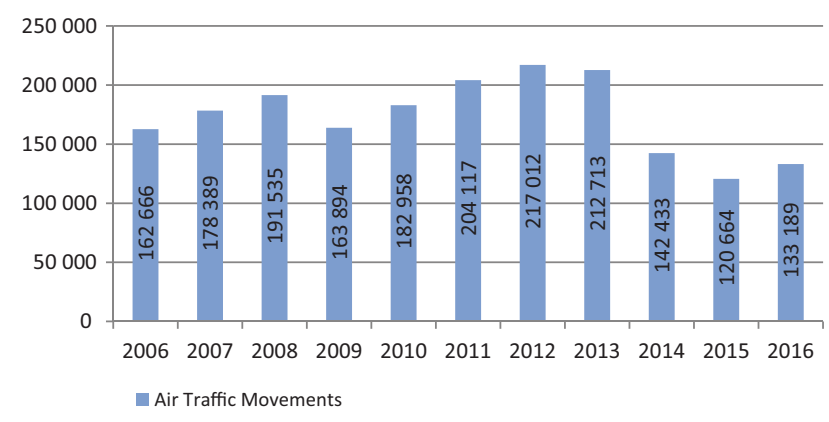

Figure 11. Air traffic movements in 2006-2016

It should be noted that about $98 \%$ of the total passenger traffic as well as mail and cargo traffic are concentrated in 7 leading airports, namely "Boryspil", "Kyiv" (Zhuliany), "Odesa", "Lviv", "Kharkiv", "Dnipro", and "Zaporizhia" (Figure 12). The "Boryspil" international airport is located successfully at the intersection of many airways that unite Asia with Europe and America. More than 40 national and foreign airlines carry out transportation of passengers and cargo from "Boryspil" using 80 regular flight routes around the world.
Due to the difficult economic conditions, decrease in passenger traffic, and some decline in the purchasing capability of Ukrainian citizens in 2014-2015, the volumes of passenger transportation at "Boryspil" airport grew to a greater extent, thanks to the successful implementation of the selected "hub" development strategy in 2016.

A $19.4 \%$ growth in passenger traffic took place at another capital airport, "Kyiv" (Zhuliany), simultaneously with almost all regional airports in Ukraine. In particular, the number of passengers serviced by the airport of Rivne has grown 8.6 times, the airport of Vinnytsia - 6.6 times, Ivano-Frankivsk - 3.9 times, Kryvyi Rig - 6.4 times, Zaporizhia - 2.2 times, Kharkiv - 60.1\%, Lviv - 29.4\%, Odesa $-8.9 \%$, Kherson $-1.6 \%$. In 2016, a decrease in passenger traffic was observed only at the airports of Dnipro (17.7\%) and Uzhgorod (75.7\%) (Oleshko \& Heiets, 2017).
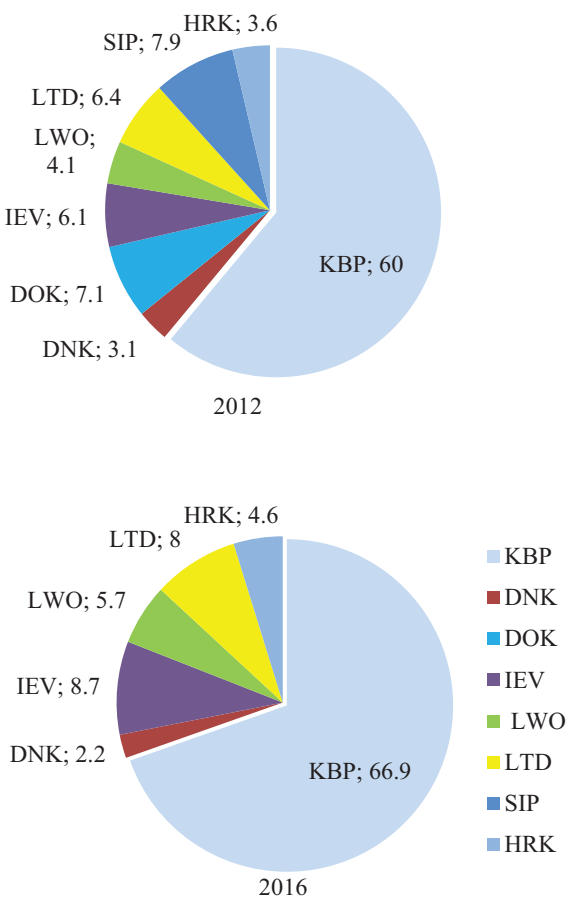

Figure 12. Market shares in the total volume of passenger transportation via the airports in Ukraine in 2012 and 2016

Despite the growth in 2016, passenger transportation within Ukraine was less popular than international transportation. The reason is the high level of expenses and the low level of paying capacity in Ukraine, as well as a developed network of rail and auto transport. The low demand for national flights is caused by the cost of tickets. The high cost of tickets can be explained by the fact that, in Ukraine, air navigation and fuel are expensive. In the beginning of 2018, the profitability gained from a national flight to "Odesa" airport by the plane An-24 can only be achieved at a ticket price of about 1200 UAH. One can surmise that Ukrainians are more interested in flying abroad or use other types of transport if confronted with such a price for tickets. 


\section{Conclusions}

The analysis of national air transportation has shown that the share of Ukraine in the global volume of passenger traffic is not significant, namely $0.23 \%$, most of which are international air transportations. However, despite the instability of the military, political and economic situation in the state, the growth rate of air traffic in the Ukrainian segment of the global aviation market is optimistic for predicting the future development of air transportation in Ukraine.

The rapid development of Ukrainian civil aviation has led to a growing interest in the national air transportation market.

Taking into account these findings, we can conclude that the national air transportation market has got certain perspectives for successful development. First of all, this is justified by a significant growth in passenger transportation by air, the establishment of new airlines in Ukraine, namely low-cost airlines, the activities of new foreign airlines in Ukraine's airspace, the opening of new airways by Ukrainian carriers, the approval of the visa-free regime with the EU countries, and modernization and development of the existing airport infrastructure in compliance with modern requirements.

\section{References}

Alamdari, F. (2010). Flying off course IV: Airline economics and marketing. Routledge. $352 \mathrm{p}$.

Belobaba, P., Odoni, A., \& Barnhart, C. (2015). The global airline industry ( $2^{\text {nd }}$ Ed.). Wiley. 380 p.

Harrison, J. M. (2005). Pricing and revenue optimization. Stanford Business Books. 368 p.

IATA. (2016). Economic performance of the airline industry. Retrieved from https://www.iata.org/whatwedo/Documents/ economics/IATA-Economic-Performance-of-the-Industrymid-year-2017-report.pdf

Kulayev, Y., \& Shchelkunov, V. (2010). Economics of civil aviation of Ukraine. Monograph. Phoenix. 736 p.

Miziuk, V. (2014). The global experience gained in the area of aviation security financing. Aviation, 18(2): 91-93. https://doi.org/10.3846/16487788.2013.865951

Oleshko, T., \& Heiets, I. (2017). Analysis of the current state of aviation of Ukraine. Problems of a systemic approach in the economy, 5(61), 80-84. Kyiv: Press of the National Aviation University.

Ozer, O., \& Phillips, R. (2012). The Oxford handbook of pricing management. Oxford University Press. 912 p. https://doi.org/10.1093/oxfordhb/9780199543175.001.0001

State Aviation Administration of Ukraine. (2016a). Spreading its wings: 2016 was a record year for Ukrainian airlines. Retreived from https://delo.ua/business/raspraviv-krylja-2016-god-stalrekordnym-dlja-ukrainskih-aviakom-327447/

State Aviation Administration of Ukraine. (2016b). The results of the aviation industry in Ukraine for 2016. Retreived from https://avia.gov.ua/wp-content/uploads/2017/04/Pidsumkyroboty-2016.pdf

World Trade Organization (2016). Aviation benefits beyond borders 2016. Retreived from https://aviationbenefits.org/media/149668/abbb2016_full_a4_web.pdf 